Swarthmore College

Works

Spring 2013

\title{
The Rise Of Dz-Manga In Algeria: Glocalization And The Emergence Of A New Transnational Voice
}

\author{
Alexandra Gueydan-Turek \\ Swarthmore College, agueyda1@swarthmore.edu
}

Follow this and additional works at: https://works.swarthmore.edu/fac-french

Part of the French and Francophone Language and Literature Commons

\section{Recommended Citation}

Alexandra Gueydan-Turek. (2013). "The Rise Of Dz-Manga In Algeria: Glocalization And The Emergence Of A New Transnational Voice". Journal Of Graphic Novels And Comics. Volume 4, Issue 1. 161-178. DOI: $10.1080 / 21504857.2013 .784203$

https://works.swarthmore.edu/fac-french/29

This work is brought to you for free by Swarthmore College Libraries' Works. It has been accepted for inclusion in French \& Francophone Studies Faculty Works by an authorized administrator of Works. For more information, please contact myworks@swarthmore.edu. 


\title{
The rise of Dz-manga in Algeria: glocalization and the emergence of a new transnational voice
}

\begin{abstract}
This article aims to establish Algerian manga as a new object of study within the field of Francophone studies and the broader field of cartooning in the developing world. To this end, it provides a survey of existing works while answering three main questions: how has manga become part of the cultural habits of young Algerian creators and readers? What status does it hold in local cultural production? Finally, what strategies have artists employed to broaden the readership of Algerian manga and how have they taken advantage of the unique possibilities offered by this new medium?
\end{abstract}

Keywords: manga; Algeria; Francophone; globalization; local publishing

During a research trip which included a visit to the 2011 international festival of bande dessinée in Algiers, I was stunned by an encounter that defied all expectations based on my academic study of Algerian visual art and literature: alongside famous local artists and caricaturists such as Slim and Le Hic stood a cluster of booths dedicated to Algerian manga. In contrast to the rather small and quiet crowd attracted by their internationally renowned peers, the manga artists were overrun by enthusiastic adolescents and young adults looking to purchase the most recent volume of a manga magazine or the latest Algerian shōjo manga or shōnen manga.

The manga artists and their devoted audience were particularly incongruous from the perspective of the postcolonial theoretical framework that typically informs criticism of contemporary Algerian culture. I approached the festival believing that the history of Algerian literature was so intertwined with Algeria's colonial history and fight for independence that all works of interest generally reference, in one way or another, the complex relationship between Algeria and its ex-colonial metropolis, France. Indeed, this is a frequent trope within Algerian literary criticism, and it often leads to the pigeonholing of contemporary Algerian cultural works, which are identified either as consequences of the colonial legacy or as a local response to the challenge of Western mass culture.

Manga, of course, breaks with this pattern. While it is universally identified with a specific country, Japan, it cannot be considered the artifact of a colonial relationship. Similarly, the appropriation of manga by Algerian artists cannot be cleanly framed as a rebellion against a foreign cultural form: while a growing number of studies have explored the dissemination and 
reappropriation of the medium outside of Japan, nowhere are these local oeuvres conceived as reactions against the global medium- and, I will argue, neither should the emergent works within Algeria.

In this article, I aim to examine the new role manga has come to occupy within the Algerian literary landscape, and to explore the dynamics of its production and circulation within the domestic market. After a discussion of the historical context that fostered the emergence of manga in Algeria, I will analyze the cultural imperatives within the contemporary Algerian publishing market that are now shaping its direction. I will show how manga lends itself particularly well to the renewed cultural agenda of post-colonial nations such as Algeria and will examine the diversity of expressions that Algerian manga has explored. Finally, within the Algerian cultural landscape, I will show how manga is able to provide new artistic voices which credibly address established cultural traditions, and how it has become a paradoxical, yet effective medium for emerging local artistic perspectives.

\section{The birth of 'Dz-manga'}

Dz-manga has come to encompass a variety of oeuvres that differ widely in how they relate to their Japanese predecessors; in this article, I use the term to refer to any Djazairi (Algerian) manga. These disparate works are united by their use of references to and techniques from Japanese manga: they frequently use drawing styles derived from it, often incorporate the stylized aesthetics and facial portrayals that popularly characterize the medium, and occasionally even refer directly to characters or plotlines from famous works. Within this loose commonality, however, lies a broad spectrum of stylistic variations. Books produced by Algerian manga publisher Editions ZLink are carefully modeled after the Japanese format, in stark contrast to those produced by young-adult literature publisher Kaza Editions, which are colorized and read left-to-right.

Formatting differences in Algerian manga productions derive in part from assumptions held by publishers about the expectations of their readership. The colorized, left-to-right formatting of Kaza Editions emphasizes the historical connection between Algerian artists and FrancoBelgian graphic traditions, easing the reader from a familiar style into narrative plots and iconography inspired by Japanese shōnen manga which might otherwise seem alienating. In contrast, Editions Z-Link's publications follow the emerging interest of Algerian readers in cultural models outside of Europe. ${ }^{1}$ Works in this spirit strictly follow the aesthetic formalisms of Japanese manga, including right-to-left pagination, stereotyped facial 
features such as oversized doe-eyes, caricatured facial emotions, and expressive dialogue bubbles.

Although manga was only recently introduced to Algeria, its current popularity can be traced to the appearance on Algerian airwaves of its televised sister, the anime. In the 1980s, Algeria's lone state-controlled national television channel (then the Radio Télévision Algérie [RTA], later renamed Entreprise Nationale de Télévision [ENTV]), broadcasted youth programs that featured Japanese animated TV series dubbed in Arabic and French. These programs were largely an oddity: at a time when mass media explicitly aimed to differentiate Algerian national identity from Western influences, the RTA was pressured by the Ministry of Information and Culture to favor local productions and shows from the Arab world. ${ }^{2}$ The RTA, however, was often unable to answer this growing demand (Amin 1996, Rugh 2004); following the example of nearby Arab countries, it chose Japanese animation as an economical and culturally accessible alternative to American animation. As a result, anime such as Grendizer or Captain Majed ${ }^{3}$ made an indelible mark on youth growing up in the 1980s, leading Yacine Haddad (2008) - a rising star in the Algerian manga community - to dub this generation 'la génération otaku' (otaku, a Japanese word for a particular type of nerdy manga fan, has been reappropriated by communities outside of Japan to generically suggest a manga enthusiast).

The prevalence of anime in Algeria increased rapidly starting in the late 1980s, facilitated by both technological and political factors: the rapid spread of cable and satellite access at that time coincided with a short-lived political liberalization (1989-1992) and the corresponding decrease in state control over programming (Amin 1996, Rugh 2004). Algerian viewers responded readily, rapidly developing an enthusiastic following for French translations of anime from across the Mediterranean (Bouchène 2010). ${ }^{4}$ By the turn of the millennium, satellite television further expanded the market, bringing anime dubbed in Arabic to Arabophone viewers, on networks such as the Middle East Broadcasting Center (MBC) and Spacetoon (both from Dubai), as well as Tunisian Radio and TV (TRT). The emergence of broad Algerian interest in manga coincided with this growth in demand for anime. Furthermore, like anime, Algerian manga's growing fan base included a heterogeneous selection of linguistic communities: unlike much print media and literature, the new works were equally able to attract Arabophone and Francophone readers. More recently, the rise of the Internet age further enhanced the spread of manga in Algeria: video-sharing technologies have made a wide selection of anime available at little or no cost, and Algerian otakus' blogs have brought together the community of manga enthusiasts, encouraging the development and exchange of fanmade productions and scanlations (amateur captionings of foreign comics). 
By the end of the 2000s, publishers finally found it feasible to start commercially supporting manga production: Kaza Editions, and Lazhari Labter Editions, both publishers of youth literature, began publishing manga in 2011, ${ }^{5}$ and Editions Z-Link, the first publisher dedicated entirely to manga was founded in 2007. Among these, the most notable is Editions Z-Link: with a specific focus on developing new artists and bringing them to the market, Z-Link predominantly publishes small-format, softcover, black and white manga books with a small Dz-manga icon in the bottom-left corner of their jackets. These run either as independent volumes or, on rare occasions, as installments in a small series (Victory road). They are printed on lowquality paper, allowing locally published volumes to remain affordable. This combination of publication strategies has enabled Algerian manga to circumvent the financial barrier to access that young Algerian consumers face with imported manga and even local BD albums. ${ }^{6}$ Easy to serialize, ZLink's low-cost medium has also helped artists to compete - at least on a local level - with foreign manga that admittedly are more intricate and include higher quality graphics.

Editions Z-Link and Kaza Editions both pride themselves on 'horizontal integration' of their in-house management, where the artists are given full control over all steps of the publication of their product - from creation, to editing, publishing, and distribution. Editions Z-Link goes even further, working to foster new talent until it can gain a truly public following: traditional calls for submission are supplemented by scouting of unpublished works on blogs, Facebook pages and other collective platforms used by fan communities online. Aspiring artists are encouraged to reach out to an audience, so that budding amateurs, who previously created for friends, can develop a wider fanbase and become published artists. Typically, new artists first publish short installments in Z-Link's monthly manga and gaming magazine, Laabstore, before being commissioned to produce a small print run (500-1,000 copies) of an independent volume. This structure permits Editions Z-Link to reconfigure the traditional publishing channels and capitalize on its position between conventional publication and selfproduction. It provides the infrastructure for autonomous artists to achieve local print runs at a reasonable cost. Since their creation, Editions Z-Link and Kaza editions have developed an enthusiastic and loyal following. Their catalogs, however, remain limited in number and difficult to procure, as the works are still distributed through a capillary network including a few bookstores in Algiers, Oran and Constantine. ${ }^{7}$

\section{An ambiguous cultural status}


In addition to the many conventional difficulties that Dz-manga has overcome in order to be successfully marketed in Algeria - such as the low literacy rate and the limited purchasing power - Algerian manga authors have also been impeded by a lack of broadly recognized cultural status. Contrary to dessins de presse and $\mathrm{BD}$, which have successfully established a tradition with their commentary on current Arab events and Algeria's colonial history (Lent 2008, McKinney 2008), manga has not yet established an identity internally within the Algerian cultural landscape. This lack of tradition is compounded by the nature of manga itself: its relative newness, its constitutive topical heterogeneity, and its complete independence from French-Algerian postcolonial rhetoric make manga a free agent, without a well-defined market or tradition. Recognizing this, producers of manga have attempted to graft their art onto other causes and traditions in order to expend Dz-manga's appeal and insinuate it into broader Algerian culture.

Kaza Editions' director and graphic artist Selim Zerdani, for example, integrated manga into his efforts to develop elementary literacy. He justifies his choice to publish a manga in Modern Standard Arabic (MSA) with his personal imperative to guide readers toward better reading: 'Beaucoup de gens ne savent pas parler correctement cette langue [l'arabe classique], donc il est légitime d'orienter les lecteurs vers de la bonne lecture' [Many people do not know how to speak this language [classical Arabic] properly, thus it is only legitimate to direct readers toward a good reading] (Zerdani 2009b; emphasis is mine). Zerdani's valuative judgment echoes biases against dialectal Arabic as an improper language which were cultivated by the last forty years of the Algerian government's linguistic policy. Implicitly, however, his judgment also promotes manga as a respectable form of literature, inviting educators and parents alike to consider it an informal educational tool. Zerdani's work effectively legitimized Algerian discourse about manga, helping to broaden its market and to provide a new voice for Zerdani's ideas about Arabic literacy.

Other manga works in Algeria employ a similar strategy: authors attempt to expand the resonance of their works by appealing to established tropes within Algerian culture. Matougui Fella's and Salim Brahimi's shōjo manga Nahla et les Touareg (2010), for example, uses the openness of the manga format to present Touareg culture. In Nahla et les Touareg, the title character, lost in the desert, is rescued by a Touareg and brought back to his camp. During her stay there, she learns about different facets of Targui culture: artifacts and musical instruments such as the Imzad and the Tindé figure prominently, as well as geographic markers such as the Ihaguen peak, and even some of the Tamashek language spoken by the Targui tribes (Figure 1). Published for the Ahaggar Arts International Festival, celebrating the cultural heritage of this Saharan region, Nahla et les Touareg provides an 
extremely effective-didactic yet fashionable-mode of transmission of Targui culture to urbanized Algerian youth.

Dz-manga's utility as a voice for local concerns arises from its flexibility as a medium. Local concerns are fused with global aesthetics, irrespective of the boundaries that demarcate other literatures. Street politics mix casually with religious topics. Specific traits borrowed from Japanese manga pair with styles and themes characteristic of comics and FrancoBelgian style BD. The same circumstances that gave rise to this fluidity have permitted a renewed exploration of creative forms in Algerian manga: as this new medium grows, new creative politics are being explored as well.

One notable example is Selim Zerdani's Le voyage de la Mouette/ Rihlet en Nawress (2009-2011), a collaborative effort between Zerdani and twelve other graphic artists, published by Zerdani's own publishing house, Kaza Editions. Prior to 2009, large collaborative endeavors of this type were rare. As with comics and manga, important works typically transcribed the vision of a single artist or, at most, were the product of a small collaborative group (an illustrator, a scriptwriter, and perhaps an inker).

By contrast, the style of Le voyage de la Mouette: au coeur de l'aventure (2011) is consciously heterogeneous. This volume tells the story of Rym, the Dey's niece, who has been kidnapped by a band of pirates modeled after the group in Oda Eiichirō's famous Japanese manga series Wan pisu [One piece ] (1997-ongoing). Although each chapter narrates a particular episode which is part of an overarching plotline, the separate sections are designed by various artists, and convey multiple parts of the story in entirely different styles. The fourth volume, for instance, includes six chapters produced by seven guest artists and Selim Zerdani himself. The diverse styles of the many artistic contributions showcase each artist's particular aesthetics and narrative voice. Selim Zerdani's 'Prologue' (pp. 210) opens the volume with a section stylistically inspired by Marvel/DC comics, with computer aided graphics incorporated into a solid black background combined with a more textually mediated narration (Figure 2). This contrasts sharply with the volume's second chapter, a comic interlude entitled 'Psycho Antar,' drawn by Natsu (pp. 11-28). 'Psycho Antar' borrows comic features primarily associated with manga, where a depiction of characters' physical transformations is used to convey their emotions (Figure 3 ). This chapter also shifts focus away from the main narrative of the collection, choosing instead to concentrate on the secondary character of Antar, an extralucid pirate, whom Natsu mocks and portrays as a deluded therapist. The chapters following these are similarly unique in their style and conception: Kouza Houria Khawla's pastel colored 'L'Ile du paradis' (pp. 29-46) has a gouache and crayon paint-like quality to its drawing (Figure 4), while Louerguioui Elhadi's 'Destruction' (pp. 55-77) combines distinctive 
characteristics from the European BD tradition (such as the ligne claire), with a narrative flow which is evocative of shōnen manga (where exaggerated movement lines emphasize violence in the fight scenes).

Although it is not my intent to explore the demands placed on the reader by this sort of composite literary system, it is important to note the active engagement that such works demand of their audience in the creation of meaning. Readers must decide whether to approach each chapter as a selfcontained independent work, or, if not, how to read it in conjunction to the rest of the plot and other volumes. They are placed into an active hermeneutic role as they must negotiate the different perspectives that are simultaneously present within a single story.

Viewing this collective experiment as a whole illustrates the way in which manga and its European and American counterparts are seen by Algerian graphic artists: not as mutually exclusive, but rather as complementary media that can bring together diverse readerships. The foreign analogues to the different strains of Algerian graphic art- manga, $\mathrm{BD}$, and comics - are often defined by their differences with each other; collectively produced manga such as Le voyage de la Mouette, instead, bring diverse sources together with new modes of affiliation based on nonhierarchical relations. In such works, artists draw their stylistic choices from an array of ideas which are neither localized nor confined, creating a composite structure which forces readers to move consciously in a world marked by a transnational fluidity of images and references.

Other Algerian works - meta-comics deploying self-reflexive narratives that question the conventions of Algerian comics (or the lack thereof) - convey a similar sense of groundlessness. One such work, 'Une histoire de BD' by Nattif (pseudonym of Attif Naas Araba) shows this notion by portraying the thought process underlying the creation of an Algerian comic. At the opening of the comic, the narrator depicts himself as an artist confronted with a white page, unsure of both his subject matter and style. The next four frames drawn from the author's own thought process recount different versions of the climactic scene from the Star Wars saga where Luke Skywalker learns that he is Darth Vader's son. Skillfully juxtaposing disparate narrative and graphic elements, these scenes invoke a web of references: first, the Marvel Comics adaptation of the Star Wars trilogy, then the ligne claire tradition (with Morris's character Lucky Luke substituted for Luke Skywalker), and finally, manga, invoked through a typically stylized sweat drop falling from Darth Vader's helmet to manifest his exasperation. The narrator discards each frame as 'ridiculous': he is unsatisfied because these works fall short of true creativity and instead duplicate existing foreign graphic works. In stark contrast to this dismissal, however, I would argue that the comic portrays hybridity as a central motivating force in 
contemporary Algerian graphic creations. Ignoring the playfulness of the subject matter and of its presentation, 'Une histoire de BD' reveals the highly composite nature of Algerian comics as an open system, bringing together disparate traditions that have come to include manga.

Hanane Bennediouni's shōjo manga Nour el-Mouloud (2011) similarly takes advantage of the blank slate that Dz-manga offers to play an interesting social-critical role. First published as part of the 2011 religious festival 'Tlemcen, capital de la culture islamique,' Nour el-Mouloud makes a critical commentary about the outward practice of Islamic traditions in contemporary Algerian society as a perversion of religious ideals. Narrated by a young female protagonist, Amina, Nour el-Mouloud centers on the preparations her family makes to celebrate the birth of the Prophet Muhammad, the Aid al Mouloud. Amina's brothers' wishes to disrupt the festivities with fireworks are counterposed against her efforts to enact a more traditional candle procession. Despite a comparatively simple narrative, this manga is able to raise serious questions about whether or not firework displays honor Islam, ultimately critiquing the materialism currently associated with religious ritual. The pedagogical structure of the work carefully drives this message home: in an epilogue, Bennediouni explicitly delivers a conservative moral lesson associating Algerian cultural identity with the sole practice of traditional Islam: "Les traditions représentent notre identité...Gardez cette petite lumière tout au fond de vous, celle qui fait ce que vous êtes aujourd'hui" [Traditions embody our identity...Keep this flicker of light deep in you, it makes who you are today] (2011, p. 129).

This tendency of Dz-manga storylines to address larger issues is not, however, limited specifically to shōjo manga and its female readers. In his Mortal combat inspired shōnen manga, Said Sabaou moves out of the cultural realm into the politico-social one. Houma fighter: round 1 (2012) relates the story of Sofiane, a professional kick-boxer and aspiring harrag (an illegal immigrant who makes his way to Europe from the Maghreb via boats). When his career faces a dead-end after he is caught cheating, Sofiane believes he is left with no choice but to attempt the perilous crossing of the Mediterranean in the hope of a better life. To pay for his trip, he must fight in underground tournaments, where he unexpectedly is instilled with moral values and brought into a community. Because of this evolution, Sofiane ultimately renounces his illegal crossing and stays in Algeria. Offering a reversal of the harraga motif, streetfighting teaches Sofiane - and, through him, young male readers - about competition, friendship and sports ethics.

Zerdani, Fella and Brahimi, as well as Bennediouni and Sabaou all support the market for Algerian manga by using it to serve existing cultural projects or to echo popular demands for societal reforms. At the same time, cultural authorities in the government also encourage manga as part of their 
commitment to strengthen local cultural production. This imperative has been particularly pressing since the early 2000s, following the civil war of the 1990s, the associated decline in the domestic publishing industry, and the related flight of many intellectuals (including bédéistes such as Slim). Algeria now finds itself in an undesirable situation where most of its literature and comics are imported. In a country where almost $50 \%$ of the population is under 25 , imported cultural works are largely unaffordable and Algerian youth risk becoming a lost generation of readers. Dz-manga responds to nearly all of these problems - it is local, culturally resonant, economical to produce, and particularly appealing to Algeria's young adults.

The efforts of the Algerian government to encourage manga production are most apparent through three recently created festivals which have played an important role in increasing the visibility of Dz-manga. The largest of these, the 'Festival International de la Bande Dessinée à Alger' (FIBDA) occurs each fall in Algiers. Although not specifically focused on manga, peripheral activities accompanying it serve to foreground the medium. Notable recent events have included cosplay contests organized by Editions Z-link and projections of anime, such as FIBDA's 2011 showcasing of Shinkai Makoto's Kumo no mukō, yakusoku no basho sponsored by the 'Centre algérien du cinéma' (CAC) and the Japan Foundation. The two other festivals are more specialized: 'Métal Manga' and the 'Shin Japan Saiten' seek to broaden public access to international and local manga, and to air award-winning Japanese anime in local movie theaters.

These festivals enjoy variable levels of official public support: the FIBDA is partially sponsored by the Ministry of Culture, whereas Métal Manga and Shin Japan Saiten are sponsored by local organizations such as the 'Office de promotion de la culture et artistique' (OPCA). They are designed to provide an open venue, with free admission, where artists can meet their public and sell a large part of their stock at lower 'festival' prices.

The FIBDA publishes two catalogues each year: the first aims to provide a survey of exhibits, while the second offers a selection of 'meilleurs albums.' Both are primarily reserved for exhibitors and guest artists, and are not released to the general public at the festival. Throughout the catalogs, different types of graphic art rub shoulders without any distinction based on media or country of origin. In 2011, for example, manga represented roughly $10 \%$ of the works featured in the selection (Dz-manga alone accounted for six percent), and the Dz-manga magazine Laabstore was featured prominently in the Fanzine section among only eight featured magazines devoted to comics. Although this placement does not earn any royalties for the artists, it does foreground certain works for the festival-wide drawing competitions, which offer lucrative prizes to encourage young artists and support their future creative endeavors. ${ }^{8}$ 
While traditional cultural gatekeepers (scholars, critics, and journalists) are still slow to recognize the cultural value of Dz-manga, it is clear that Algerian manga artists have successfully mobilized more traditional forms of cultural capital and institutional support to gain legitimacy for their works. Prizes at the FIBDA in 2009 and 2011 have recognized manga as a serious contender within the much broader field of graphic art, reflecting the extent to which local manga can rapidly gain a foothold in popular culture when it confronts serious cultural issues in an authoritative voice. ${ }^{9}$

Natsu's Degga (2009), the first manga to receive the highest award at the FIBDA, clearly demonstrates this trajectory towards cultural authority. A light-hearted depiction of family quarrels surrounding quasi-legal sheep fights occurring in celebration of Eid al-Adha, Degga traces the story of a young man, Salim, who dreams of earning glory in the annual fight, but who repeatedly fails because of the weak animals that his father spares him. The story details Salim's efforts to transform 'Coton,' the scruffy creature he is eventually given, into a vicious fighter that will bring him fame at the next year's contest. Embedded within this whimsical narrative, however, is a network of subtle references and social commentary. The name of the victorious creature that fills Salim's dreams, "Eva 05," is drawn directly from Anno Hideaki's Japanese anime Shinseiki Evangelion [Neon Genesis Evangelion] (1995-1996) which recounts a war waged by teenagers piloting humanoid cyborgs called "Evas" against evil invaders. At one point, Salim even thanks his father in transliterated Japanese (Figure 5).

Perhaps more importantly, Degga presents a biting commentary on culture, gender and the politics of performance that sustain animal-fighting among Algerian youth. Its storyline questions the public display of masculinity in contemporary Algerian society, where adolescent males must fight to assert their dominance and value to others. Just like Nour elMouloud and Nahla et les Touareg, this manga adopts a position of cultural authority, exploring the negotiation of Islamic religious symbols in the face of modernity.

Strategies such as these, however, are not without risk: despite the fact that Dz-manga is starting to benefit from recognition by some cultural authorities, it remains to be seen whether it can aspire to the status of an artform à part entière (analogous to La nouvelle manga in France), or whether it will be construed as a mere instrument of a cultural or religious agenda. Furthermore, critics may ultimately deem it paradoxical if a foreign form becomes the recognized medium for the safekeeping of specific Algerian cultural traditions. Rather than being a risk, however, I believe that this is an asset: that the study of Dz-manga is interesting and relevant 
precisely because it provides an alternative to the pervasive postcolonial France-Algeria narrative typically applied to contemporary Algerian culture.

\section{A protean cultural form}

According to a postcolonial interpretive framework, contemporary Algerian cultural productions respond to past French dominance and its colonial legacy, leading many scholars to foreground a body of literature that is predominantly published in France. Dz-manga breaks this mold, as a local product which has been created for a domestic audience following a model entirely beyond the Franco-Algerian cultural axis. This independent positioning, furthermore, is not incidental: Algerian cultural practitioners have openly acknowledged the appeal of Japanese-inspired Dz-manga as an alternative to Western cultural forms. Renowned bédéiste Slim, for example, argued for manga (and similar projects), saying that the time was right for young artists to distance themselves from cultural forms imported from France. ${ }^{10}$ Similarly, the Algerian press appears to encourage the spread of this new medium in their reporting on the FIBDA. The national daily $E l$ Watan thus declared that artists should no longer be subservient to the graphic traditions inherited from the ex-colonial power, and that a present need for stylistic renewal should be recognized: 'On ne peut plus se cantonner dans le style franco-belge. Aujourd'hui, c'est l'ère de la jeunesse et du renouveau' [We can no longer be bound by the French-Belgian style. Today is an era of youth and renewal] (Chabani 2011). A limited reading of El Watan's call for a new graphic tradition would see this passage as nothing more than a plea to expand the range of aesthetic options for Algerian readers. Interpreting it as an aesthetic judgment, however, ignores (or denies) the transformative role that cultural production and consumption can play in the establishment of self-image.

In "Encoding/decoding," (1980) Stuart Hall has emphasized the agency of consumers in the establishment of cultural identity. According to Hall, the active consumption of cultural artifacts can allow the object of consumption to become an integral part of a group's identity. Following this line of argument, I would add that transnational circulation of 'new' cultural forms such as manga in Algeria should be welcomed as the emergence of a site of negotiation for Algerian cultural identities outside of the colonial paradigm. Interestingly, El Watan's call relays none of the fears of 'manga invasion' and cultural dissolution that were prevalent in the West when manga first appeared. While Algeria is certainly not impervious to asymmetrical cultural exchanges and logics of domination, these factors are apparently less relevant in the specific case of manga: Questioning its 
cultural imperialism would draw into question the escape from Western imperialism desired by Algerian cultural practitioners and consumers. Furthermore, it would risk confusing Western cultural imperialism with Japan's particular practice of soft power. ${ }^{11}$ Instead, artworks derived from Japanese models within Algerian local cultural markets can have very positive effects: they create a space beyond the binary Maghreb vs. France and contradict the old tenet that the colonial metropolis serves as the main purveyor of models to Algerian culture.

Rather than viewing the emergence of manga in Algeria as an act of cultural colonialism, it can be understood as a process of creolization whereby the imported cultural form is subject to a complex process of cultural reappropriation. Through this process, Dz-manga is wholeheartedly adopted by Algerian practitioners, demonstrating a relationship between globalization and local production that is no longer antagonistic. Extensive work by cultural anthropologists has explored the emergence of foreign cultural forms in local areas, and the extent to which transnational cultural flows can foster new artistic forms (Hannerz 1991, Hall 1991, 1995, Appadurai 1996). In a seminal work on this topic, Ulf Hannerz (1991, p. 124) spoke of the 'creolization of culture,' suggesting that 'cultures, like languages, can be intrinsically of mixed origins, rather than historically pure and homogeneous.' Considering the network of effects produced by such transcultural exchanges, Arjun Appadurai notably argued that, rather than leading to global cultural homogenization, foreign influences are adopted and mixed with local elements through a process of 'indigenization' (Appadurai 1996, p. 198).

Elaborating on the ideas of Hannerz and Appadurai, Massimo Repetti (2007) suggests that the rise of African cartooning in past decades is an outward sign of the cultural melding that results from increased transnational flows of cultural goods, people and capital. Although Repetti and Hannerz differ in their views of 'creolization' (Repetti sees it as a historically and geographically situated process rather than an integral component of culture), both agree on the generative potential inherent to such exchanges:

The exchange has nothing to do with Western colonialism, with unidirectional cultural influence imposed on the colonized subject to the point of provoking either unconditioned adhesion or rejection. It is more a relationship between, on the one hand, the comics created in a large-scale process in industrialized countries (America, Japan, Europe) that tend to be conceived for and read by a "globalized" audience, and on the other hand, African authors who change styles, acquire different knowledge, and make creative contributions to their societies that are richer than the local cultures in which they originated. (Repetti 2007, p. 16) 
Repetti is interested in the dynamic of creolization for its ability to produce aesthetic, cultural and power relations between the emanating and the reappropriating cultures that are unlike those historically experienced within colonization and imperialism. Where imperialist influences are often tied to cultural dissolution and global homogenization, Repetti argues that creolization can foster an increased diversity of genuinely local works. $\mathrm{He}$ implies that the mixing and hybridization resulting from the encounter of heterogeneous cultures in African comics facilitates transnational exchanges and helps incorporate localized productions into a global marketplace.$^{12}$ This argument highlights the agency of historically dominated subjects, while entirely avoiding narratives of victimization. Indeed, the primary appeal of the creolization hypothesis lies in the shift that it implies for the postcolonial subject: instead of being a passive victim who merely receives first world commodities, creolization implies an active agent who reshapes them before consuming them.

Bearing these considerations in mind, the presence of manga in Algeria should not be interpreted as a pale reflection of a Japanese artform and a manifestation of cultural alienation within Algeria; instead, we should see it as the reflection of a society first pulled into - and now actively participating in - a global cultural marketplace. Dz-manga represents a fascinating artifact: the combined result of global cultural trends, local Algerian strategies of indigenization, and the particular fluidity of manga as a medium.

In the past, critics have called attention to the limitations of this process of appropriation: because comics are ubiquitous, and because the graphic art tradition in Algeria heavily relies on foreign formats, any emergent trends in Algerian graphic art were immediately deemed suspicious. Allen Douglas and Fedwa Malti-Douglas, in particular, have noted that the predominance of French in Algerian comics could transform such works into a 'linguistic battlefield' and the ideological stronghold of Francophonia (Douglas and Malti-Douglas 1994, p.175). Although I have argued elsewhere in agreement with their identification of the unique role of the French language in Algerian graphic art among Arab cultures, I believe that contemporary creolization in Dz-manga reveals limitations to this argument. During the past decade, the language in comics has evolved: graphic artists and scriptwriters now take frequent discursive liberties, mixing French with Darija (Algerian Arabic), Modern Standard Arabic and even Tifinagh in drawings and speech balloons. Similarly, Algerian art now explores aesthetics beyond those derived from the ex-colonizer - including, but not limited to, manga. 
The unique role that manga has been able to adopt is due as much to the nature of manga as a mediumas it is to the geopolitical implications of its use. Manga specialist Iwabuchi Kōichi has noted that manga's glocal appeal arises from its ability to intertwine familiar elements with alien aspects. Iwabuchi thus conceives of manga as a privileged site of cultural negotiation which is at its core both 'nationless' (1998, p. 167) and 'culturally odourless' or mukokuseki [non-Japanese] (2002, p. 27). Partly because of this cultural openness, Dz-manga has emerged as a natural site for the interplay between the languages in use in Algeria. The low-cost printing methods of Z-Link and Kaza editions have made it easy - and not uncommon - for publishers to release versions of the same volume in different languages. Even within a single printing, language is typically quite fluid: Francophone publications typically employ popular expressions in Darija, whereas Arabic-language manga often vacillate between dialectal and modern standard Arabic. In the Francophone version of Bennediouni's Nour el-Mouloud (2011), for instance, Darija appears transliterated into Roman characters to mark a change in the protagonists' mood, even when nearby panels contain Arabic script (Figure 6). In addition, Tifinagh script occasionally shares the page with French, as in Fella and Brahimi's Nahla et les Touareg (2010).

Whether because of its foreign origins, the protean nature of the medium, or the mixture of languages that has emerged in recent works, Dz-manga inherently defies any monocultural characterization. This, in turn, has allowed manga a unique positioning relative to Algerian society: when the French language is used in Algerian manga, it can then invoke specifically Algerian concerns without any appearance of being, per Douglas and MaltiDouglas, a 'bastion of Francophonia' (Douglas and Malti-Douglas 1994, p. 175).

\section{Renewing Algerian creative politics}

The Dz-manga presented in this article represents a unique emerging medium within the Algerian artistic landscape. Despite the fact that its introduction was partially a byproduct of the policies of Algeria's statesponsored television station, Dz-manga has risen to an unexpected position of popularity and cultural authority. Recently founded publishing houses dedicated to Dz-manga have encouraged its growth, and the attention of a variety of festivals with different cultural agendas has facilitated the development of an ability to address local concerns in a voice that does not convey any of the cultural overtones of other comparable media.

By considering Dz-manga as a transnational cultural product, one gains insight into the unique role that Dz-manga plays for Algerian artists and readers. As an adopted, creolized medium which does not carry any of 
the (post)-colonial implications of other westernized media or artforms, Dzmanga is a blank slate that has been free to address a range of Algerian social issues, cutting across linguistic and cultural barriers within Algeria.

Ultimately, the level of success of manga in Algeria will be determined by consumers, critics, artists, and publishers. Despite its growing acceptance, social, political, or economic trends could easily reverse its gains. While it is unlikely that it will evolve into a recognized ONJ artform, on par with La nouvelle manga in France, it remains a remarkable example of transnational success within Algeria, where it has become a genuine, trusted voice for local expressions.

\section{Notes}

1. In the opening pages of one manga, local, right-to-left Arabic reading habits were tied explicitly to the Japanese manga tradition: "Cette bande dessinée est au format manga, par consequent le sens de lecture est de droite à gauche; a se lit comme un livre arabe." [This bande dessinée follows manga styling. Accordingly, the reading direction goes from right to left; it reads like an Arabic book.] (Fella 2010, panel 2)

2. In Algeria, local TV stations have played a major role in relaying governmental policies and preserving a national unity through a set of core values. As Hussein Amin has demonstrated, governmental control of this mass media often serves as 'a mean to filter programs' (1996, p. 126). From this perspective, content of youth oriented programing merited particular scrutiny and, in this context, one could rightfully expect Japanese manga shown on TV at that time to have had their content vetted by higher authorities. Unfortunately, the data regarding this particular instance is too slim to allow us to conclude whether or not that was the case.

3. Respectively, UFO Robo Grendizer (74 episodes, Tōei Animation, 1975-77), from a manga by Nagai Gō; better known in France as Goldorak and in the United States as Grandizer. Captain Tsubasa (128 episodes, Tsuchida Production, 1983-86), from a manga by Takahashi Yōichi; better known in France as Olive et Tom and in the United States as Flash Kicker.

4. According to Mohamed Benrabah, by the mid-1990s, French TV programs were watched by nine to 12 million of Algerians; in 2003, 52\% of Algerian households continued to prefer watching French TV channels over foreign and local stations in Arabic (Benrabah 2007, p. 105). 
5. With, respectively, the collective volumes of Le Voyage de la Mouette / Rihlet en Nawress (2009-2011), published in French and Arabic by Kaza Editions, and Said Sabaou's Mondialé ! (2011-2012), published by Lazhari Labter Editions in the collection 'JIL manga.'

6. Editions Z-Link's manga and Kaza Editions' Le Voyage de la Mouette/ Rihlet en Nawress sell, on average, for 250 DA (\$3.02), while Lazhari Labter Editions' sell for 400 DA (\$4.88); Japanese manga imported by BPMS cost between 700 DA (\$9.03) and 1,500 DA (\$19.36), and remain mostly unaffordable for the average Algerian reader. In comparison, Algerian BD published by local specialized Dalimen editions in album-format are often prohibitively expensive, ranging from 500 DA (\$6.04) to 2,000 DA (\$25.13). Selim Zerdani, graphic artist and editor of Kaza editions, notes that with the price of comics and manga rising above 150 DA, many families are forced to forego print materials in order to purchase necessities, such as foodstuffs. In the end, he concludes, editors run the risk to have potential readers 'buy food rather than a book' (Melikian 2011). As a point of reference, the World Bank estimated Algeria's 2010 gross national income per capita at $\$ 4,460$ in contrast with the United States’ per capita income of $\$ 47,140$ (World Bank).

7. While the scale of Dz-manga print runs remain small in comparison to international publications, it is nevertheless significant within Algeria's small literary market, and growing rapidly. The distribution of the monthly magazine Laabstore is variable, up to 10,000 copies. Editions Z-Link has published eighteen volumes since its founding in 2007 - each with a typical print run of $\sim 2500$ copies - but is currently undergoing a period of rapid expansion, with twelve more titles slated for release in the upcoming six months (source: unpublished correspondence with Salim Brahimi of Editions Z-link). Comparable figures were unavailable for Kaza Editions and Lazhari Labter, the other major publishers of Dz-manga.

8. The FIBDA, for example, organizes a total of three national comics contests-best work, best script and best graphics-- divided according to age groups in the following categories: Espoirs scolaires (under 18 years old), Young Talents (18-35 years old) and Professionals (above 35 years old). While the first and the last of these categories tend to attract only a single type of artists (respectively, teenage fans and confirmed artists whose recently published albums are being judged), the 'Young Talents' tends to attract a heterogeneous population including nonprofessionals who self-publish on the internet (including the 2011 winner, Houria Kouza) and young published artists submit unpublished work (such as Sofiane Belaskri who placed second in 2011, but who had just published a manga, Drahem, Ed. Z-link).

FIBDA's Best Work winners receive prizes that range from 100,000 DA $(\$ 1,262)$ for Espoirs scolaires to 200,000 DA $(\$ 2,524)$ for Young Talents and Professionals; Best Script and Best Graphic receive from 70,000 DA to 120,000 DA ( $\$ 883.40$ $1,514.40)$ depending on the age group. Second and third runners up receive 
between 50,000 DA-80,000 DA (\$631-\$1,009.60) and 70,000-150,000 DA

(\$883.40-\$1,893) respectively (bdalger.net).

9. Natsu's Degga (Ed. Z-link, 2009) won first prize in 2009 and Oudjiane Sid Ali featured in $3^{\text {rd }}$ position for his album published as a chapter within Le Voyage de la Mouettel Rihlet el Nawress (Kaza editions, 2011). Despite the gender implied by his chosen Japanese pseudonym, Natsu (in real life, Mohamed Taher Aïdaoui) is male.

10. Unpublished interview with Slim conducted at the 2011 FIBDA, Algiers, 13 October 2011.

11. Although not universally so, the penetration of manga abroad has been linked to the concept of 'soft power' as defined by Joseph Nye. 'Soft power,' according to Nye, designates ways through which a country can exert its influence in foreign affairs without having recourse to traditional economic and military policies, what Nye calls 'hard power' (2004 cited Napier 2007, p. 6). In the case of Japan, the expression 'soft power' points to the cultural influence that Japan has exercised abroad through the seduction that its popular culture (anime, manga, horror movie and music) held over other nations. For instance, manga and anime actively served to soften the image of the Japanese non-combat troops (Self Defense Force, SDF) in US-occupied Iraq: The Japan Foundation provided the largest Iraqi TV station the third season of the Captain Tsubasa anime series free of charge, while the SDF troops painted the popular shōnen and anime character, Captain Tsubasa himself (Captain Majed in Arab countries) on their trucks (Lam 2007, p. 354).

12. While Repetti's analysis provides a more nuanced account of the relation between globalization and local cultural production in developing African countries, as he does not conflate globalization and neo-imperialism, he appears to overstate the role of creolization of comics, which he defines as a two-way process that implies an equal and "mutual exchange" between the emanating culture and the reappropriating cultural entrepreneurs (Repetti 2007, p. 16). 


\section{References}

Amin, H., 1996. The Middle East and North Africa. In: A. Wells, ed. World broadcasting: a comparative view. Norwood, NJ: Ablex Publishing Corporation, 121-144.

Appadurai, A., 1996. Modernity at large. Minneapolis: University of Minnesota Press.

Belaskri, S., 2011. Drahem. Alger: Editions Z-Link.

Benmesbah, A., 2003. Un système éducatif en mouvement. Le français dans le monde, 330, $12-13$.

Bennediouni, H., 2011. Nour el-Mouloud. Alger: Editions Z-Link.

Benrabah, M., 2007. The language planning situation in Algeria. In: R. Kaplan, ed. Language planning and policy in Africa, vol. 2. Tonawanda, NY: Multilingual Matters Ltd, 25-148.

Brahimi, S., et al., 2009-2012. Laabstore, vol. 1-32. Alger: Editions Z-Link.

Bouchène, Y., 2010. Dis-moi quelle est ta tribu, je te dirai qui tu es.... El Watan Weekend edition, 17 September, Tendances. Available from : http://www.elwatan.com/archives/rubrique.php?ed=2010-0917\&rub=ew:w:weekend:magazine:tendances [Accessed 06 October 2011].

Chabani, N., 2011. On ne doit plus se cantonner dans le style franco-belge. El Watan, 12 October, Culture. Available from : http://www.elwatan.com/archives/edition.php?ed=201110-12 [Accessed 25 November 2011].

Douglas, A., and Malti-Douglas, F., 1994. Arab Comic Strips: Politics of an Emerging Mass Culture. Bloomington: Indiana University Press.

Elhadi, L., 2011. Destruction. Khawla, K.H., 2011. L'Ile du paradis. In : Zerdani, S., ed. Le voyage de la Mouette : au cour de l'aventure, vol 4. Alger : Kaza Editions, 55-77.

Fella, M. and Brahimi, S., 2010. Nahla et les Touareg. Alger: Editions Z-Link.

Haddad, Y., 2008. Génération Otaku: le vaisseau manga atterrit à Bab-Ezzouar. Le soir d'Algérie, $\quad 26 \quad$ February. Available from : http://www.lesoirdalgerie.com/articles/2008/02/26/article.php? sid=65001\&cid=16 [Accessed 27 November 2011]

Hall, S., 1980. Encoding/Decoding. In: S. Hall, D. Hobson, A. Lowe, and P. Willis, eds. Culture, Media, Language:working papers in cultural studies 1972-79. London: Hutchinson, p. 128-38.Hall, S., 1995. New cultures for old. In: D. Massey and P. Jess, eds. A place in the world? Places, culture and globalization. Oxford: Oxford university Press, 175-211.

Hall, S., 1997 [1991]. The local and the global: globalization and ethnicity. In: A. King, ed. Culture, globalization and the world-system. $2^{\text {nd }}$ ed. Minneapolis: University of Minnesota Press, 19-39.

Hannerz, U., 1997 [1991]. Scenarios for peripheral cultures. In: A. King, ed. Culture, globalization and the world-system. $2^{\text {nd }}$ ed. Minneapolis: University of Minnesota Press, 107-128.

Iwabuchi, K., 1998. Marketing 'Japan': japanese cultural presence under the global gaze. Japanese studies, 18 (2), 165-180.

Iwabuchi, K., 2002. Recentering globalization: popular culture and Japanese transnationalism. Durham: Duke University Press.

Kaplan, R., ed., 2007. Language planning and policy in Africa, vol. 2. Tonawanda, NY: Multilingual Matters Ltd.

Khawla, K.H., 2011. L'Ile du paradis. In : Zerdani, S., ed. Le voyage de la Mouette : au cœur de l'aventure, vol 4. Alger : Kaza Editions, 29-46. 
King, A., ed., 1997 [1991]. Culture, globalization and the world-system. $2^{\text {nd }}$ ed. Minneapolis: University of Minnesota Press.

Lam, P.E., 2007. Japan's quest for 'softpower': attraction and limitation. East Asia, 24, 349363.

Lent, J.A., 2008. Vignette: The horrors of cartooning in Slim's Algeria. In: J.A. Lent, ed. Cartooning in Africa, Cresskill, NJ: Hampton Press, 84-89.

McKinney, M., 2008. The frontier and the affrontier. European Comic Art, 1 (2), 175-199.

Melikian, L., 2011. Trois générations d'auteurs algériens au festival international de BD d'Alger. ActuaBD [online], 22 October. Available from : http://www.actuabd.com/Trois-generations-d-auteurs [Accessed 7 May 2012].

Métaoui, F., 2009. Les enfants des manga sont làEl Watan, 18 October. Available from : http://www.elwatan.com[Accessed 06 November 2011]

Napier, S., 2007. From Impressionism to anime. New York: Palgrave Macmillan.

Nattif, 2009. Une histoire de BD [online]. Available from : http://www.4shared.com/photo/Qs0kTQgP/Une_Histoire_de_BD.html and http://www.4shared.com/photo/ut3LzBn0/Une_Histoire_de_BD_2.html [Accessed 11 November 2011]

Natsu (Aidaou, M.), 2009. Degga. Alger: Editions Z-Link.

Natsu (Aidaou, M.), 2011. Psycho Antar. In : Zerdani, S., ed. Le voyage de la Mouette : au cour de l'aventure, vol 4. Alger : Kaza Editions, 11-28.

Repetti, M., 2007. African wave: specificity and cosmopolitanism in African comics. African arts, $40 \quad$ (2), 16-35. Available from : http://www.mitpressjournals.org/doi/pdf/10.1162/afar.2007.40.2.16 [Accessed 7 May 2012].

Rugh, W., 2004. Arab mass media: newspaper, radio and television in Arab politics Westport, CT: Praeger Publishers.

Sabaou, S., 2010. Mondialé ! vol. 1. Alger: Lazhari Labter Editions.

Sabaou, S., 2011. Mondialé ! vol. 2. Alger: Lazhari Labter Editions.

Sabaou, S., 2012. Houma fighter: round 1. Alger: Editions Z-Link.

Wells, A., ed., 1996. World broadcasting: a comparative view. Norwood, NJ: Ablex Publishing Corporation.

Zerdani, S., et al., 2009a. Le voyage de la Mouette : stratégie obscure, vol 1. Alger : Kaza Editions.

Zerdani, S., 2009b. 'J'ai un savoir faire, alors je m'en sers !' Entretien avec Selim Zerdani), auteur et éditeur de BD algérien. AfriBD [online] Interview by C. Cassiau-Haurie. 16 October. Available from: http://www.afribd.com/article.php?no=10180 [Accessed 10 November 2011].

Zerdani, S., et al., 2010. Rihlet en Nawress, vol. 1-3. Alger : Kaza Editions.

Zerdani, S., et al., 2011. Le voyage de la Mouette : au cœur de l'aventure, vol 4. Alger : Kaza Editions.

Zerdani, S., 2011. Prologue. In : Zerdani, S., ed. Le voyage de la Mouette : au cour de l'aventure, vol 4. Alger : Kaza Editions, 2-10. 